\title{
淡明細胞肉腫と診断された一軟部腫痬例の検討
}

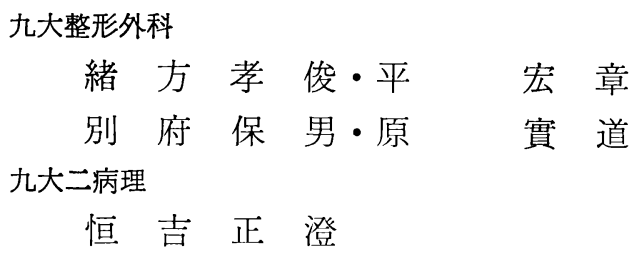

\section{A Discussion Study on A Soft Tumor Classified as A Clear-cell Sarcoma of Tendons \& Aponeuroses}

By

\author{
T. Ogata, H. Taira, Y. Beppu \& H. Hara \\ Department of Orthopedic Surgery. \\ Faculty of Medicine, Kyushu University \\ M. Tsuneyoshi \\ Department of Pathology, Faculty of \\ Medicine, Kyushu University
}

\begin{abstract}
A 26y-ear-old man developed a sarcoma in his left adductor magnus with inquinal metastasis which classified as was a clear cell sarcoma of tendons and aponeuroses.

Conforming to the original description of clear cell sarcoma in many clinical and pathological points, electron microscopic examination from the excised material revealed ultrastructure of melanin.

Evidence for a cutaneous melanoma was, however, lacking. This kind of tumor, therefore, must be considered as provisionally named "malignant melanoma of soft parts".
\end{abstract}

緒言

1965 年, Enzinger ${ }^{2)}$ は主に四肢の大きな腱組織に 生ずる肉腫で，臨床病理学的に比較的特徽的な一群の 疾患を報告し，細胞学的な特徽から腱および腱鞘の淡 明細胞肉腫と命名した。その後本腫煬に関する報告が 相次ぎ，その発生起源に関して電顕的な検索もみられ るようになったが，その起源についてはまだ十分に解 明されたとはいえない1145)567)。

われわれは, 最初淡明細胞肉腫と㟝断されて当院を 紹介され, 摘出腫場の電顕的検索で細胞質内にメラ, ソームが認められた症例に遭遇し，てれを治療する機 会を得たので文献的な考察を加えて報告する.
症例

26才, 男性, 船員.

主訴：左坐骨部腫瘁形成.

家族歴，既往歴：特記すべきととなし。

現病歴：昭和 48 年 6 月どろ，考えられる誘因もな く，左坐骨結節部に生じた母指頭大の腫瘤に気づいて いたが放置していた。 その後昭和 49 年 5 月でろに左 そけい部の小指頭大の腫瘤を触れるようになり，昭和 49 年 6 月 1 日市立戸畑病院整形外科を受診, そけい 部腫煬の試験切除を受けた。組織学的検查で「腱およ び腱鞘の淡明細胞肉腫」の謬断を与えられた。（九大 病理組織診断 No. 71690)

同年 6 月 17 日に九大整形外科の外来を受部， 6 月 
19 日に入院した。

入院時听見: 体格中等, 栄鏊状態良好, 貧血その他 全身状態の悪化を思わせる所見は認ぬない，左そけい 部に試験切除の手術創が見られ，左坐骨結節部に近い 軟部組織内に約 $10 \mathrm{~cm} \times 2 \mathrm{~cm}$ の腫溜を認めた。腫瘤 は皮屬との瘾着はないが, 基底部とは強く瘾着して動 かない，硬度は硬く，境界は比校的明瞭である，柽度 の圧痛は認めるが，局所の発赤，熱感などの炎症所見 は認めない。

術前の諸検査でも著変なく，血沈值も 1 時間値 7 , 2 時閵值 19 で亢進をみない。

X線検査では，骨および胸部の異常影を認めない．

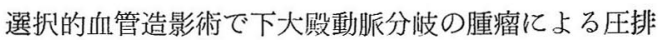
像が観察されるが，腫煬性新生血管の増生はない（図 1 ).

手術所見：腫瘤は圭側大内枟筋内に存在し，内 側で陰茎勃起筋，基底部で坐骨結節の骨膜と線維 性の強い瘳着を示したので電気メスで切放した。

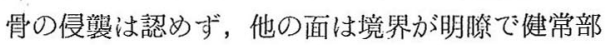
と容易に分けられる。皮下㧍よび脂肪組織内一の 浸润手認》られない。

腫瘍の肉眼的所見：摘出した腫瘤は $7 \times 3.5 \times$ $3 \mathrm{~cm}$ で赤褐色を呈し，弾性硬で表面は輅い凹凸

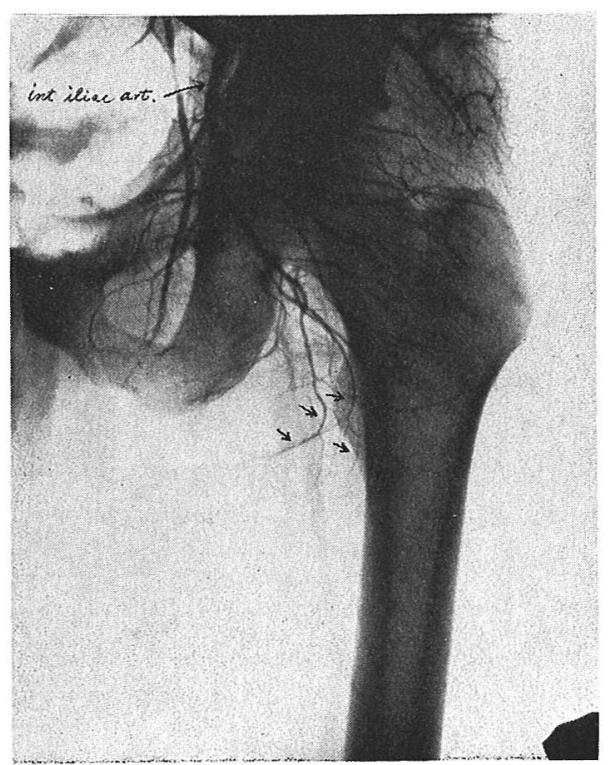

図1.血管造影所見: 腫瘤による下大殿動脈分枝 の圧排像が認められる。
を示す，明らかな被膜は見られない，割面は灰白また は黄白色を呈し，均質で允実性の一見線維性腫瘍組織 より成り, 出血策, 壊死巢は部分的にも認められな い. 中心部は特に板状に硬い。

組織学的所見：緔鍾形ないし類円形の淡明な腫湯細 胞が，不規則な胞巣状に配列している（図 2)。腫㿟 細胞の細胞質は明るく, あるものは弱好酸性を示し， 細胞境界は明瞭である、核は細胞のほぼ中央にあり比 較的大きい（図 3 )。核染色質は豊富であるが，やゃ 大きな㤥小体が好塩基性に濃染し顕著である。全般を 通してて細胞はほぼ均一であり，しか子密に存する，多 核巨細胞はどてにも認められない，光顕レベルでは細 胞質内に褐色の顆粒状色素は認められない，PAS 染 色は軽度陽性であるが，アルカリフォスファターゼ，

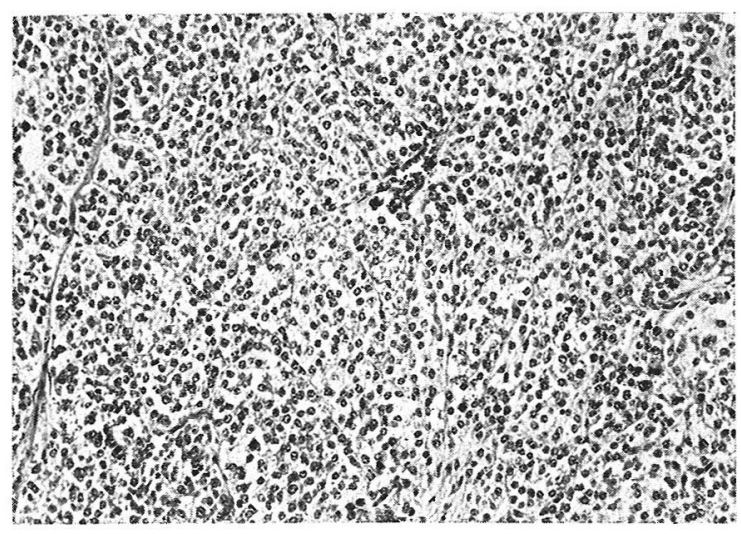

図2、病理組織所見: 淡明細胞が充実性胞巣状に 配列している.

(九大 中検 $51988, \mathrm{HE}$ 染色, 250X)

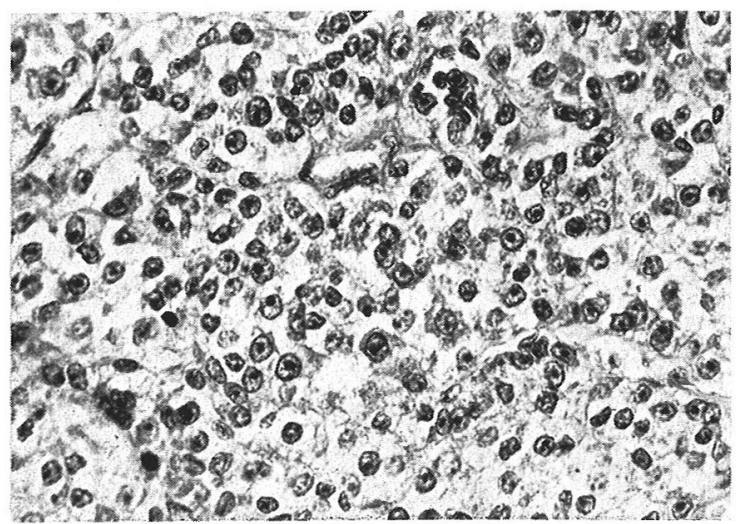

図 3. 同上強拡大像：核は核膜が明膫である. (九大 中検 $51988, \mathrm{HE}$ 染色, $660 \times$ ) 


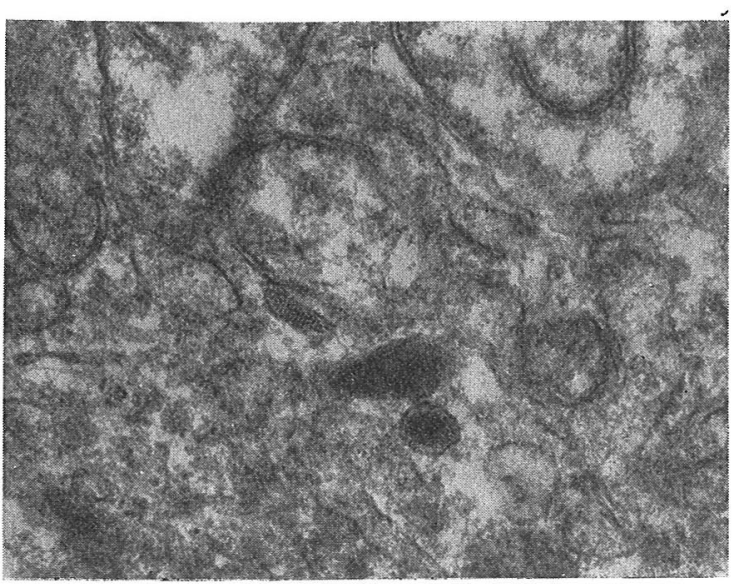

図 4. 電子顕徽鏡所見: 第 $2 \sim 4$ 期のメラノソーム がみられる。

(酢酸ウラニール・酢酸鉊二重染色, 80, 000X)

酸フォスファターゼ, Sudan III 等の酳素染色ではい ずれも陰性である。

電子顕徴鏡的所見：新鮮な手術材料を $3 \%$ \%ルター ルアルデヒドで 3 時間前後固定を行ない, カコジレー 卜緩衝液で 1 時間洗浄し，1\%オスうュウム酸で 1 時 閒後固定して,エチルアルコールで脱水処理したのち， エポン樹脂に包埋した。トルイジンブルー染色による 厚切標本の結果, 細切した薄切標本を酢酸ウラニル, 酢酸鉛の二重染色をして，JEM 100 B で観祭した。 明調な細胞と暗調な細胞の混在がみられる. 主として 明調な細胞に高電子密度の顆粒がみられ，それらは第 2 期加第 4 期のメラノームから成る（図4).

術後経過：術後経口的に 1 日量 $100 \mathrm{mg}$ のエンドキ サン投与を総計 $5,000 \mathrm{mg}$ 続け, 手術創の治瘾を待っ て退院した。 その後他院で局所のコバルト照射を総計 5, $000 \mathrm{rads}$ 受けた。昭和 49 年 12 月現在, 腫厡の再 発，転移は見られていない。

\section{考}

按

本例は，左坐骨結節部の軽部組織内に生じた腫瘤を 放置するうちと，同側のそけい部に転移を来した時点 で受彰し，試硂切除の結果，腱および腱鞘の淡明細胞

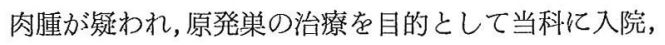
その後の電子顕徴鏡的検索で悪性黒色腫とみた方がよ いと考えられたものである。

Enzinger ${ }^{2\rangle}$ が淡明細胞肉腫として報告した21 例は AFIP の過去におけるファイルの中から選ばれたもの
で,それまでは滑膜肉腫, 線維肉腫, 胞䆚状軟部 肉腫，悪性黑色腫などと診断されていたものであ る、そして彼は腫瘍の臨床病理学的な「わくず け」を行なったものの，その組織起沙はなお不明 で電湿的な検䇣の必要性を強調している。 久保 $(1969)^{5 〉}$ は組織学的に淡明細胞肉腫と診断された 1例を電晋的に䳽察して，（1）ダリコーゲンを 多量に含む大型明涯細胞とてれを含まない小型暗 調細胞との 2 種類の細胞が存在するとと, (2) 基底膜と偽腺管構造の疜在，（3） filopodia,

(4) electron-dense bodies の存在などから滑 膜肉腫の範疇に属するものと考えた。この種の腫 痬に，光顕的に䶂色の顆粒状色素を認めた報告に は, 今までに Enzinger ${ }^{2)}$, 久保 ${ }^{5)}$, Hoffman ${ }^{4}$ らの記述がある。しかし Enzinger ${ }^{2) は F o n t a n a-~}$ Masson 染色で陽性であったがメラニン漂白試検

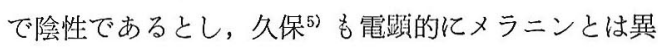

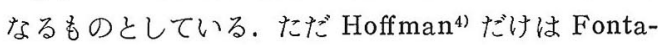
na-Masson 染色で陽性であったのを電顕的にメラノ ソームと同定している。彼の例は，淡明細胞肉腫と診 断された腫瘍を摘出した 2 年後に再発した腫瘤を組織 学的ならびに電顛的に觀察したものであり，光䫓的に すでに褐色色素が細胞質内に認められた，以上の專央 から彼は淡明細胞肉腫の神経外胚荣起源を唱えてい る. この例は 2 回目手術後約 4 力月で死亡し, 経過中 そ多発性の皮下腫瘤を生じたり，著明なリンパ節の檕 移な来したりして，悪性黑色腫の経過と同一であった と記載されている。われわれの例は, 蜼床病理学的な 面からみれば淡明細胞肉腫と異なるのである。しかし 電顕的に明らかに各段階のメラノ一ムを証明すること ができた。われわれは久保の報告した例（大塚らのの 報告と同一例) の光䫓標本と電顕写真とを自ら観察す るととができたが，光顕像の類似性に反して，電显像 は今回の例と多くの点で明らかに異なっている。した っがて, 淡明細胞肉腫自身を黑色腫と共通の神経外胚 菒起源に持って行くよりは，本例のごとくメラニンの 証明される腫瘍は滑膜起源を示唆できるものとは区別 して取り扱い，淡明細胞肉腫の中には入れずに軟部悪 性黑色腫 malignant melanoma of soft parts とし て独立させるべきではないかと思う。そして淡明細胞 肉腫とされたものを注意深く分析すればての範嚋に入 るものがいらか選出できるのではなからうか。 
結

語

26才男子の左坐骨結節部の 軟部組織内に 発生した 淡明細胞の像を示す腫瘍例を検討し, 電顕的にメラノ ソームを検出した。この種の腫瘍は腱および腱鞘の焱 明細胞肉腫とは区別し, 軟部黒色腫として取り扱うべ きと思われる.

稿を終るに臨み, 終始ご指導, ご校閲の労をいとわ ず本論文の完成に御助力頂いた九州大学二病理遠城寺 宗知教授に深謝いたします．なお本論文は厚生省軟部 腫瘍研究班の助成金による研究の一環として九州大学 整形外科西尾教授の援助を頂いた.

\section{文献}

1) Dutra, F. R.: Clear cell sarcoma of tendons and aponeuroses. Cancer. 25: 942-946, 1970.

2) Enzinger, F. M.: Clear cell sarcoma of tendons and aponeuroses: An analysis of 21 cases. Cancer. 18: 1163-1174, 1965.

3）福代良一・他：悪性黒色畽の細胞学的分類. 西 日皮唐. 34:87-101，1972。

4) Hoffman, G. J.: Clear cell sarcoma of tendons and aponeuroses with melanin. Arch.
Pathol. 95: 22-25, 1973.

5) Kubo, T.: Clear cell sarcoma of patellar tendon studied by electron microscopy. Cancer. 24 : 948-953, 1969.

6)大塚久・山本喜昭：膝蓋靯帯より発生した炏明 細胞肉腫 (clear-cell sarcoma). 癌の臨床. 12 : 453-455, 1966.

7) 徳久俊雄 - 他: 谈明細胞肉腫 (clear-cell sarcoma）の 1 例. 整形外科と災害外科. 22:3537, 1973.

澌問鳥大整形 前山旅

プレメラノゾームまたはメラノゾールを見出された とのことですが，その意義について御意見を伺いた い.

回答 九州大学整形外科 緒方 孝俊

Hoffmann の報告では, 初発時に clear cell sarcoma であった症例の再発部にメラニンを認めて, clear cell sarcoma の histogenesis に関して malignant melanoma と同じカテゴリーに属するもの と考えた。

われわれの例も，乙れに近い例と考えるが，現在の とてろ, malignant melanom であると考えざるを 得ない.

\title{
高度の骨侵襲を示した平滑筋肉腫の 1 例
}

\author{
鹿児島大学整形外科 \\ 森 本 典夫・東成 昭 \\ 鹿児島大学第 2 病理 \\ 坂 江 清 弘
}

\section{Leiomyosarcoma of Left Foot with Extensive Destruction of Tarsal Bone. Report of a Case}

By

\author{
N. Morimoto and H. Higashi \\ Department of Orthopedic Surgery, Faculty \\ of Medicine, Kagoshima University \\ K. Sakae \\ Second Department of Pathology, Faculty \\ of Medicine, Kagoshima University
}

A house-wife, aged 39, with leiomyosarcoma involving the bone was reported. The pa- 